This report was prepared as an account of work sponsored by the United States Government. Neither the United States nor the United States Atomic Energy Commission, nor any of their employees, nor any of their contractors, subcontractors, or their employees, makes any warranty, express or implied, or assumes any legai liability or responsibility for the accuracy, completeness or usefulness of any information, apparatus, product or process disclosed, or represents that its use would not infringe privately owned rights.

In the interest of prompt distribution, this LAMS report was not edited by the Technical Information staff.

Printed in the United States of America. Available from National Technical Information Service

U. S. Department of Commerce 5285 Port Royal Road

Springfield, Virginia 22151

Price: Printed Copy $\$ 30$, Microfiche $\$ 0.95$

$$
04.00
$$




\title{
Radiation-Hardened Magnets Using Mineral-Insulated Conductors
}

\author{
by
}

A. Harvey

This report is based on a paper published in the Proceedings of the Fourth International Conference on Magnet Technology, Brookhaven, September 1972. It has minor revisions and has been updated. 

the United States nor the United States Atomic Energy Commission, nor any of their employees, nor any of their contractors, subcontractors, or their employees, makes any warranty, express or implied, or assumes any legal liability or responsibility for the accuracy, completeness or usefulness of any information, apparatus, product or process disclosed, or represents that its use would not infringe privately owned rights.

RADLATION-HARDENED MAGNETS USING IINERAL-INSULATED CONDUCTORS

by

A. Harvey

\section{ABSTRACT}

A unique Feature of the LAMPF high-intengity linac experimental area Is the extensive use of inorganic magnet coils to withstand the high radiation doses expected.

In a large number of these magnets the coll insulation is compacted magnesium oxtde powder ("mineral insulation," m. $i_{\text {.) }}$ and pre-insulated cable is wound into the requited coll conflguration. Although the cable itself is expensive compared to bare copper conductor, the finished coll cost is comparable to a conventional coll, since no insulation application Is required of the coll winder.

Two conductor formats are used at LAMPF: solid conductor, externally cooled, using soft solder to improve the heat transfer within the coll; and directly cooled, hollow conductor m.1. cable. At LAMPF both conductor types are coneervatively rated. Indirectly cooled colls are used exclusively In the awitchyard magnets, where low fleld strengths and high qualfty are required. Higher-power magnets for target-to-target trangport and secondary beam lines use direct cooling. Methods of making teminations on the cable are described.

Measured operating parameters for all these magnets are tabulated. Poleshaping techniques for the bending magnets and quadrupoles are examined and the results given.

\section{INTRODUCTION}

One of the dominant problems facing the designers of the LAMPF experimental area was the antic1pated high radiation dose arising from the high intensity of the beam. The $1 \mathrm{~mA}$ average current of $800 \mathrm{MeV}$ protons impinging on a target such as graphIte or molybdenum is expected to produce radiation doses in the target cells of $10^{11}-10^{12} \mathrm{rad} / \mathrm{yr}$. "Conventional" magnet Insulations (e.g., epoxyfiberglass, with a radiation tolerance of $10^{10}$ rad max) were ruled out, and after some consideration, "mineral-insulation" was dectded on for the maln

beam line and some secondaries.

"Mineral-1nsulation" is a term from the wire and cable industry, used to describe an electrical insulation of metal oxide (usually magnesium oxide). The oxide is in the form of a powder, generally held around the copper conductor by a copper sheath (see F1g. 1). Although multiple conductor formats are

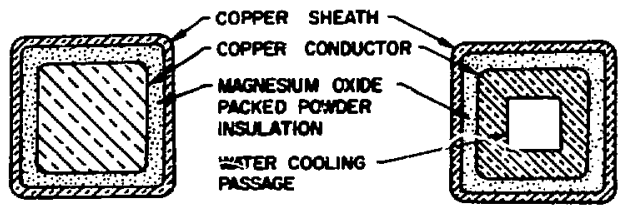

\section{MINERAL INSULATED SOLID CONDUCTOR CABLE}

\section{MINERAL INSULATED HOLLOW CONDUCTOR} CABLE

F'IG.

common in the industry, only one conductor is requiled for magnet coll fabrication. The development needed was to make the cable square, to improve packing in a coll, and to provide direct conductor cooling for higher current densities.

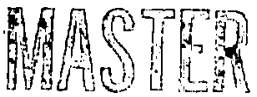


This paper 11lustrates the successful achievement of these objectives. It should be noted that at present there are only two plants 1n North AmerIca with the capability of producing the cables described here: Pyrotenax of Canada Ltd., in Trenton, Ontario, Canada, and General Cable Corp., In Perth Amboy, N.J. All of the m.1. cable used at LAMPF has been produced by Pyrotenax of Canada Ltd.

\section{CABLE}

Formats

Two formats of mineral-insulated cable are used at LAlPF. The solid conductor cable is a single-conductor cable of conventional cosstruction, formed square outside, and used with external cooling (Indirect cooling).

Hollow conductor cable has a hole in the center of the conductor to allow direct water cooling, and hence, higher current densities (Fig. 1). This Is a rather significant change in the usual manufacturing process for mineral-insulated cable, but has been done before. 1

\section{Manufacture}

\section{General}

Two manufacturing methods are currently employed to produce m.1. cable commercially. In the first method, short tubular preforms of magnesium oxile are pressed and baked, and then loaded fnto the annulus between the conductor rod and sheath tube. In this case the reduction in cross section by drawing is generally not great (about $50 \%$ on diameter in several draws). Each one or two draws is followed by an annealing cycle to sorten the copper.

The second method fills the annulus between the conductor rod and sheath tube (the latter about 2" o.d.) with MgO powder, tamped firmly in an assembly up to $30 \mathrm{ft}$ long. Th1s then $1 \mathrm{~s}$ reduced to the required size (with anneals as necessery between draws). In either method square cable is produced by using square dies instead of the usual circular ones for the final draws.

The maximum length of cable that can be manufactured 18 set generally by the length of the assembly at the start, and the annealing fumace uaed when the cable cannot be colled, olnce later draws use a bull-block, colling up the cable, and so are capable of handling any length of cable. Current technology gives the edge on length to the powderf11l method, and Table 1 11sta the lengths now ava1lable.

TABLE 1.

Maxtmum Available Lengths for Mineral-Insulated Cable

\begin{tabular}{lr|lr}
$\begin{array}{c}\text { Nominal } \\
\text { Size }\end{array}$ & $\begin{array}{c}\text { Maximum } \\
\text { Length }\end{array}$ & $\begin{array}{c}\text { Nominal } \\
\text { S1ze }\end{array}$ & $\begin{array}{r}\text { Maximum } \\
\text { Length }\end{array}$ \\
\hline $0.25^{\prime \prime} \mathrm{sq}$ & $1,950 \mathrm{ft}$ & $0.375^{\prime \prime} \mathrm{sq}$ & $550 \mathrm{ft}$ \\
$0.375^{\prime \prime} \mathrm{sq}$ & $820 \mathrm{ft}$ & $0.53^{\prime \prime} \mathrm{sq}$ & $220 \mathrm{ft}$ \\
$0.412^{\prime \prime} \mathrm{sq}$ & $650 \mathrm{ft}$ & $0.75^{\prime \prime} \mathrm{sq}$ & $220 \mathrm{ft}$ \\
$0.53^{\prime \prime} \mathrm{sq}$ & $410 \mathrm{ft}$ & & \\
\hline
\end{tabular}

\section{Solid Sonduct or}

Solld conductor m.1. cable for magnet use is basically a standard round, alngle-conductor, mineral-1nsulated cable, formed square in cross section. However, the Insulation thickness required by the conservative electrical licensing authorities for use in $600 \mathrm{~V}$ rated power wirting is more than a magnet designer needs, since it reduces his packing factor and the magnet voltage generally does not exceed 200v. To date we have succeeded in providing mintmal insulation thicknes only in the $0.25^{\circ /} \mathrm{sq}$ size (see Table 1). GIven sufficient Inducement there is no doubt the manufacturer could do the same in the other sizes.

Spectfications for the three sizes of solidconductor m.1. cables used at LAMPF are given in Tables 2 through 4 . The pertinent coment here 18 that the $0.412^{\prime \prime}$ square and $0.53^{\prime \prime}$ square sizes are standard circular, single-conductor m.1. cables drawn square. However, the 0.25 " sq s1ze requires a special manufacturing process (note the packing factor for this size is 32\%, quite good for such a small conductor). 
TABLE 2.

Mineral Insulated Solid

Conductor Cable, 0.25" Sq.

Specification: Overall size: $0.25^{\prime \prime} \mathrm{sq}+0.000^{\prime \prime}$
Corner radius $0.050^{\prime \prime}$ max
Conductor size: $0.157^{\prime \prime}$ nominaI square outside
Insulation thickness: $0.015^{\prime \prime}$ minimum
$\begin{array}{r}0.020^{\prime \prime} \text { nominal } \\ \text { Sheath thickness: } 0.020^{\prime \prime}+0.005^{\prime \prime} \\ -0.60^{\prime \prime}\end{array}$

Mater1als: Conductor: copper, $200 \%$ I.A.C.S. Max. resistance at $25^{\circ} \mathrm{C}: 0.4 \Omega / 1000 \mathrm{ft}$ Insulation: compacted magnesium oxide Sheath: copper, commerclal anneal. Free of burrs, nicks and scratches.

Tests: Insulation resistance, Inner conductor to outer sheath $>5,000 \mathrm{~m} / 1000 \mathrm{ft}$ at $25^{\circ} \mathrm{C}$, $100 \mathrm{~V} d c$

Dielectric strength, $>1,250 \mathrm{~V}$ rms inner conduct or to sheath, 1 min.

Immersion of colled cable (except ends)

In warm water for $30 \mathrm{~min}$. to produce no change in insulation resistance.

We1ght: $180 \mathrm{lb} / 1,000 \mathrm{ft}$

Nominal current ratirg: $125 \mathrm{~A}$

Shipping: Colled to minimum diameter of $2 \mathrm{ft}$. All ends of Insulation sealed against molsture.

TABLE 3.

Mneral Insulated Solid

Eonductor Cable 0.412" Sq.

Spectification: Overall size: $0.412 " \mathrm{sq}+0.000^{\prime \prime}$

Corner radius $0.032 "$ max

$-0.010^{\prime \prime}$

Conductor size: $0.238^{\prime \prime}$ nominal square outside

Insulation thickness: $0.030^{\prime \prime}$ minimum

$0.060^{\prime \prime}$ nominal

Sheath thickness: $0.027^{\prime \prime} \pm 0.005^{\prime \prime}$

Materials: Concuctor: copper 100\% I.A.C.S. Reslatance: $0.159 \Omega / 1000$ ft nomlial $0.169 \Omega / 1000 \mathrm{ft}$ maximum

Insulation: compacted magnesium oride

Sheath: copper, comerclal anneal. free of nicks, scratches and burrs

Tests: Insulation resistance, inner conductor to outer sheath $>5,000 \mathrm{~m} \Omega / 1000 \mathrm{ft}$ at $25^{\circ} \mathrm{C}$, $100 \mathrm{~V}$ dc

Dielectric strength $>1,500 \mathrm{~V}$ rms inner conductor to sheath, 1 min.

Immersion of coiled cable (except ends) in warm watex for $30 \mathrm{~min}$ to produce no change in insulation resistance

We1ght: $425 \mathrm{1b} / 1000 \mathrm{ft}$

Nominal current rating: $180 \mathrm{~A}$

Shipping: Coiled to a minimum diameter of $3 \mathrm{ft}$. All ends of Insulation sealed against molsture.
TABLE 4.

Mineral Insulated Sol1d

Conductor Cable $0.53^{\prime \prime} \mathrm{Sq}$.

\author{
Specification: Overail size: $0.53^{\prime \prime} \mathrm{sq}+0.000^{\prime \prime}$ \\ Corner radius 0.032 " max$$
-0.010^{\prime \prime}
$$ \\ Conductor size: $0.350^{\prime \prime}$ nominal square outside \\ Insulation tinickness: $0.030^{\prime \prime}$ minimum \\ $0.060^{\prime \prime}$ nominal \\ Sheath thickness: $0.030^{\prime \prime} \pm 0.005^{\prime \prime}$ \\ Materlals: Conductor: copper 100\% I.A.C.S. \\ Resistance: $0.0795 \Omega / 1000 \mathrm{ft}$ nominal \\ $0.0844 \Omega / 1000 \mathrm{ft} \max 1 \mathrm{mum}$ \\ Insulation: compacted magnesium oxide \\ Sheath: copper, commercial anneal, \\ Ezee frow nlcks, scratches \\ and burr \\ Tests: Insulation resistance, inner conductor to \\ outer sheath $>5,000 \mathrm{~m} / 1000 \mathrm{ft}$ at $25^{\circ} \mathrm{C}$, \\ $100 \mathrm{~V}$ dc \\ Dielertric strength $>1,500 \mathrm{~V}$ rms Inner \\ conductor to sheath, $1 \mathrm{~min}$. \\ Inomersion of colj.ed cable (except ends) \\ in warm water for $30 \mathrm{~min}$ to produce no \\ change in Insulation resistance \\ Weight: $726 \mathrm{Ib} / 1000 \mathrm{ft}$ \\ Nominal current rating: $300 \mathrm{~A}$ \\ Shipping: Colled to minimum diameter of $4 \mathrm{ft}$. \\ All ends of insulation sealed against \\ molsture.
}

\section{Hollow Conductor}

To enable direct water-cooling of the conductor, a hole is required in the center of the conductor. Again, two methods are avallable to produce this: uaing a die in the bore (either fixed or floating), or filling the bore of the conductor to prevent its collapse during drawing. This latter method requires the fllling to be easily removable for annealing and final use. Agatn, lengths avallable are listed in Table 1 . Spectfications for two sizes are given in Tables 5 and 6.

Tests

Electrical. The lectrical characteristics of the cable are of paramount importance, and in fact, because of the inherently irregular configuration of the conductor, are specified in preference to mechanical dimensions. It should be clear that the outside dimensions of the cable, being produced by drawing, can be held to close tolerances. However, the conductor itself is formed by the intermediate MgO iayer, and the outslde and Inside of the conductor are difficult to define in dimensional terms. 
TABLE 5.

Mineral Insulated Hollow

Conductor Cable $0.53^{\prime \prime} \mathrm{Sq}$.

\begin{tabular}{|c|c|}
\hline Specif Icat Ion: & Overall s1zє: $\quad \begin{aligned} 0.530^{\prime \prime} \mathrm{eq} & +0.000^{\prime \prime} \\
& -0.010^{\prime \prime}\end{aligned}$ \\
\hline Corductor gize: & $\begin{array}{l}\text { Corner radius } 0.063^{\prime \prime} \text { maximum } \\
0.36^{\prime \prime} \text { nominal square outside } \\
0.18^{\prime \prime} \text { nominal square Inside } \\
0.050^{\prime \prime} \text { mintmum wall thickness }\end{array}$ \\
\hline Insulation & $\begin{array}{l}0.020^{\prime \prime} \text { minimum } \\
0.055^{\prime \prime} \text { nominal }\end{array}$ \\
\hline
\end{tabular}

Sheath thickness: $0.030^{\prime \prime} \pm 0.005^{\prime \prime}$

Mcterials: Conductor, copper, 100\% I.A.C.S. Max resistance at $25^{\circ} \mathrm{C}: 0.091 \Omega / 1000 \mathrm{ft}$

Insulation, compacted inagnesium oxide

Sheath: copper, commerclal anneal

Tescs: Insulation resistance, inner conductor to outer sheath $>5,000 \mathrm{M} / 1000 \mathrm{ft}$ at $25^{\circ} \mathrm{C}$, $100 \mathrm{v}$ dc

Dielectric otrength, $>1,500 \mathrm{~V}$ rms inner conductor to sheath, $1 \mathrm{~min}$

Water tests: 300 psi water in central hole to produce no change in insulation reslatance

Immersion of colled cable (except ends) in warm water for $30 \mathrm{~min}$ to projuce no change in insulation resistance

Water flow: 0.5 USGPM, with max pressure drop $1.0 \mathrm{psi} / \mathrm{ft}$

Weight: $0.6 \mathrm{ib} / \mathrm{ft}$

Noninal cuzrent rating: 750A

Shipping: Colled to minimum diameter of $4 \mathrm{ft}$. Al: ends of lnsilation seslec agalnst moisture. mube ancs plugged.

\section{IABIE 6.}

Minerai Insulated Hollow Conductor Cabl: $0.75^{\prime \prime} \mathrm{Sq}$.

Specification: Overall size: $0.75^{\prime \prime} \mathrm{sq}+0.0$ j'

\section{Conductor size: $0.57^{\prime \prime}$ nominal square outside \\ $0.26^{\prime \prime}$ nominal square inside \\ $0.09^{\prime \prime}$ min wa11 thickness}

Corner radius: $0.08^{\prime \prime} \max$ $-0.01^{\prime \prime}$

Insulation thickness: $0.05^{\prime \prime}$ nominal $0.03^{\prime \prime}$ minimum

Sheath thlckness: $0.035^{\prime \prime} \pm 0.005^{\prime \prime}$

Materlals: Conductor: copper 100\% I.A.C.S. Max resistance at $25^{\circ} \mathrm{C}: 0.035 \Omega / 1000 \mathrm{ft}$

Insulation: compacted magnesium oxide

Sheath: copper, comerclal anneal

Tests: Insulation resistance, Inner to outer $>5,000 \mathrm{M} \Omega / 1000 \mathrm{ft}$ at $25^{\circ} \mathrm{C}, 100 \mathrm{~V} \mathrm{dc}$ Dielectric strength, > 1,500V rms tr.rer conductor to sheath, 1 min

Water test: 400 psi water in cercrai tole to produce no change in inguiation resistance

Hater flow: 2.5 USGPM, with max pregsure drop $200 \mathrm{ps} 1 / 180 \mathrm{ft}$

Welght: $1.4 \mathrm{lb} / \mathrm{ft}$

Nominal current rating: 1800A

Shipping: Colled to minimum dia of $4 \mathrm{ft} . \mathrm{All}$ ends of insulation sealed against moisture. Tube ends plugged.
It Is tore reasonable, then, to define (1) a conductor maximum restetance (which controls both the crosg-aectional area and the copper quality), (2) an tosulation realstance between conductor and sheach, which controls the quality (malnly dryness) of the nagnestum oxide Ingulation, and (3) a highpotential test, which controls the minimum insulation thickness. Tables 2 - 6 glve examples of such specifications.

Mechanica1. Arguments similar to those above lead to very few mechantcal parameters belng spectfled. The outside dimensions are given, with lowside tolerances only, for conventence, A comer radius $1 s$ desirable to reduce the tendency to crack at bends.

Conductor lengths are chosen to sult the particular design: the maxlma for varlous sizes are listed In Table 1.

Hydraulfc. The hydraulic tests serve two purposes: to Insure adequate cooling flow, and to insure the integrity of the sheath and conductor weil.

The water-flow test specifles a maximum pressure drop For the Fiow zequired to maintaln cooling at the rated current, and controls the cross Bection of the cooling passage. It may be noted that, agatin, this hole may be 1rregular; the common practice of blowing a bail through the cooling passage is not recommended with m.1. cable.

Two tests check the integrity of the copper enclosing the MgO insulation. An Immersion in water tries the outer sheath, while pressurizing the cooling passage with water checks the conductor wal1. Measuring insulation resistance after these tests datermines if there has been any water penetration 1nto the Mgo. Th1s test Is extremely sensitive, since the $108 s$ of insulation resistance caused by molsture is catastrophic.

\section{iII. COILS}

\section{General}

The manufacture of colls from m.1. cable $1 \mathrm{~s}$ geseraliy similar to conventional techniques, with the maln difference being that no insulation application ts required. Coll forms are standard, and tension is applied in the usual way. The relatively long lengths in which m.1. cable is 
avallable makes foining generally unnesessary: LASL practice kas been to make terminat fons and external joincs when the lengting are not adequate. An advartage $c$ tnis syezex is that, in case of insulation problams for instance, Individual sections can be isolated and tested.

A parameter of interest in coll design and fabrication is the rintmum bending radius. There are two criterla which can be used: the first, within a coll, is the amount of "keystoning" which is produced; and the second (on leads, for example) is simply the smallest radius which will not damage the cable sheath. Both criteria are listed in Table 7.

TABLE 7.

\begin{tabular}{l|cc|c} 
Cable Size & $\begin{array}{c}\text { In-coil } \\
\text { Min. Radius }\end{array}$ & Keygtoning & $\begin{array}{l}\text { Out-of-Co11 } \\
\text { Min._R-dius }\end{array}$ \\
\hline $0.25^{\prime \prime} \mathrm{sq}$ & $0.9^{\prime \prime}$ & $0.010^{\prime \prime}$ & $0.6^{\prime \prime}$ \\
$0.375^{\prime \prime} \mathrm{sq}$ & $1.1^{\prime \prime}$ & $0.012^{\prime \prime}$ & $0.75^{\prime \prime}$ \\
$0.412^{\prime \prime} \mathrm{sq}$ & $1.25^{\prime \prime}$ & $0.010^{\prime \prime}$ & $1^{\prime \prime}$ \\
$0.53^{\prime \prime} \mathrm{sq}$ & $1.75^{\prime \prime}$ & $0.02^{\prime \prime}$ & $1.5^{\prime \prime}$ \\
$0.75^{\prime \prime} \mathrm{sq}$ & $2.5^{\prime \prime}$ & $0.02^{\prime \prime}$ & $2^{\prime \prime}$ \\
\hline
\end{tabular}

It must be stressed that, in bending the conductor outside a coll, particularly to minimum radius, a mandrel and bending fixture are necessary. The copper sheath is soft and less than $0.04^{\prime \prime}$ thick, and can be damaged by local pressure. Moreover, the cable, particularly in the larger sizes, $0.75^{\prime \prime}$ sq., does not take kindly to belng re-bent. A single bending operation to the final configuration is essential in this size.

Indirect $1 \mathrm{y}$-Cooled Coils

For magnets requiring low power densities (at LAMPF, the swltchyard magnets, where flelds generally do not exceed $4 \mathrm{kG}$ because of the $\mathrm{H}^{-}$beam) it is feastble to use a solid-conductor cable, cooled extemally, to wind colls. As has been pointed out previous $1 y^{2}$, soft-soldering can be used to effect the heat transfer from conductor to cooling channels. This still seems the most economical way to provide the requisite metallic path for heat conduction: the quality of the soldering required is dependent on the heat transfer efficlency (and so, power density) required. One requirement we have found necessary is to insure that no corrosive flux remains in the final soldered assembly. We also require pre-tinning of the cable.

since heat from the conductor traverses insulation only once before being transferred by the matrix of copper sheaths and solder to the couling channels, relatively high current densitlas may be used. Table 8 gives, in addition to recommended current densitles already published, ${ }^{3}$ limiting current densities which will cause solder melting in

TABLE 8.

\begin{tabular}{|c|c|c|c|c|}
\hline Cond. Size & $\begin{array}{l}\text { Recoin } \\
\text { Current } \\
\text { Density }\end{array}$ & $\begin{array}{l}\text { nded } \\
\text { Current }\end{array}$ & $\begin{array}{l}\text { Maximum } \\
\text { Current } \\
\text { Density }\end{array}$ & $\begin{array}{c}\text { "Solidus" } \\
\text { Current }\end{array}$ \\
\hline $0.25^{\prime \prime} \mathrm{sq}$ & $5100 \mathrm{~A} / \mathrm{in}^{2}$ & 125A & $\begin{array}{l}11,800 \\
\mathrm{~A} / \mathrm{in}{ }^{2}\end{array}$ & $290 \mathrm{~A}$ \\
\hline $0.412^{\prime \prime} \mathrm{Bq}$ & $3200 \mathrm{~A} / 1 \mathrm{n}^{2}$ & $180 \mathrm{~A}$ & $\begin{array}{l}6,575 \\
A / 1 n^{2}\end{array}$ & $370 A^{t}$ \\
\hline $0.53^{\prime \prime} \mathrm{sq}$ & $2450 A / 1 n^{2}$ & $300 \mathrm{~A}$ & $\begin{array}{l}5,720 \\
\mathrm{~A} / \mathrm{in}^{2}\end{array}$ & $700 A^{*}$ \\
\hline
\end{tabular}

* 8-1ayer coil: would be less in a 10-1ayer coll.

+ Cast coil: We have seen meIting as low as 205A la a poorly soldered coll.

10-1ayer test coils, water-cooled on one side. Both these ratings depend on the quality of the soldering (1.e., the volds left in the coll). Note that the temperature rise in the cooling water of such coils is small, and by having the cooling colls on the outside of the coil, adjacent to the iron, temperature changes in the iron are winimized. This was a factor in the design of the LAMPF switchyard magnets, where high fleld quality was required (see F1g. 2).

Soldering. There are a number of ways to solder the cable and cooling-coll assembly together. We outline three methods here, with their relative advantages and disadvantages, but three features are comnon to them all. 1) Tinning the cable before (or during) winding is the only way to insure that solder wets the sheath Inside the coll. 2) The coll dinensions have to be maintalded durIng soldering. Steel banding straps will hold the coll cross section, and are easily removed after soldering, as the atrap 18 not wet by solder. 3) Any corrosive fluz must be excluded from the finlshed coll assembly. Since removal is difficult, the safest course is to solder the pre-tianed parte without using flux. This is quite practical if care 19 taken to avold excessive oxtdation of the tinning. 


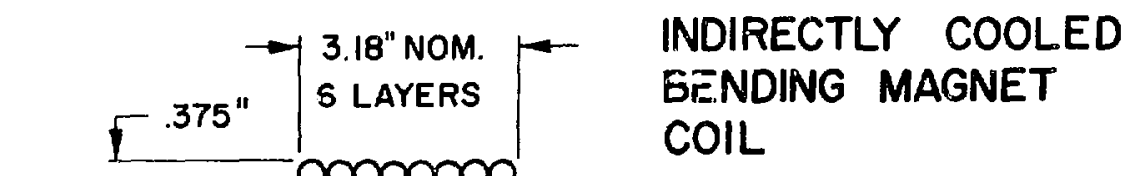

\section{INDIRECTLY COOLED GUADRUPOLE COIL}

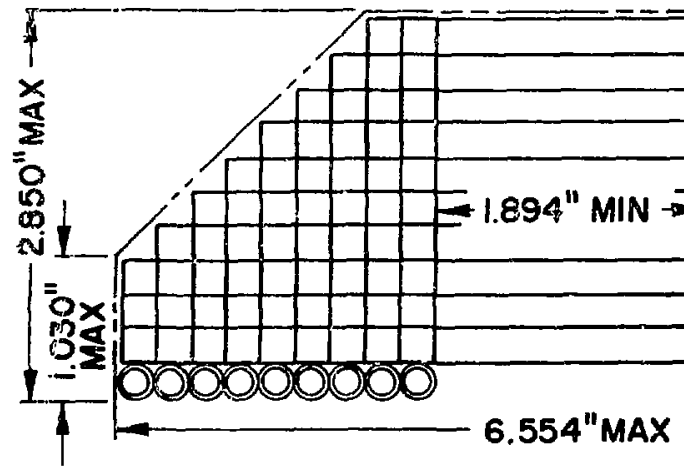

A. Dfp Soldering. This requires a solder bash larger than the coll assembly to ba soldered, so Is probably the most expensive method of the three. Firther, it is necessary to remove the coll from the bath at a temperature as close to the solidus point as possible, otherwise most of the salder simply runs out of the coll. It is difficult: to provide vold-free construction this way.

B. Casting. Here the coll assembly is placed in a mold and wolten solder is poured in. Preheating of the cofl seems destrable to insure penetration to the Inside of the coll, but if this is doni, this method produces the best filling of the cofl, hence the maximum heat transfer. This method ha: been used in-house, evacuating the mold and coll be fore casting, or simply furnace-heating both.

c. Resistance Heating. The coll may be heated electrically (using the conductor) and solder applied from the outalde, usually with the assistance

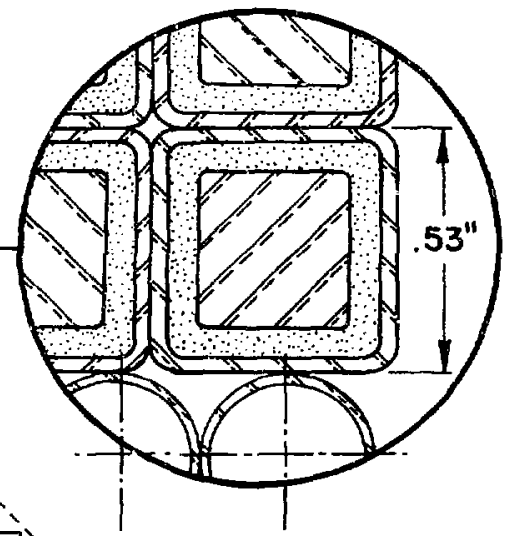

.25 " SQ. M.I. CABLE 62 TURNS

$\frac{1}{4}$ "O.D. COPPER

TUBING. 9 TURNS

FIG. 2

of local torch (flame) heating. A chill plate on the bottom of the coll prevents excesstve loss of solder (a cooling cotl may be used as the chill plate). This is probably the cheapest method of soldering the coll, as no special equipment $1 \mathrm{~s}$ required, but the quality of the job depands on the care which is taken, and some judgment is required of how much bolder to add to the coll to fill most of che internal volds. However, for conservative ratings, such as are used at LAMPF, the results are perfectly satisfactory.

Terminations. The sealing of the MgO Insulation (to keep molsture out) is a problem colmon to solid and hollow conductor m.1. cables. Since the radiation environment dictates the use of an $1 \mathrm{n}-$ organic insulation in the cable, non-organtc seals are used at LAMPF. A fatrly standard ceramtc-tometal seal (see Fig. 3) 1s squared at the larger end to fit the cable sheath. Nickel ends form 


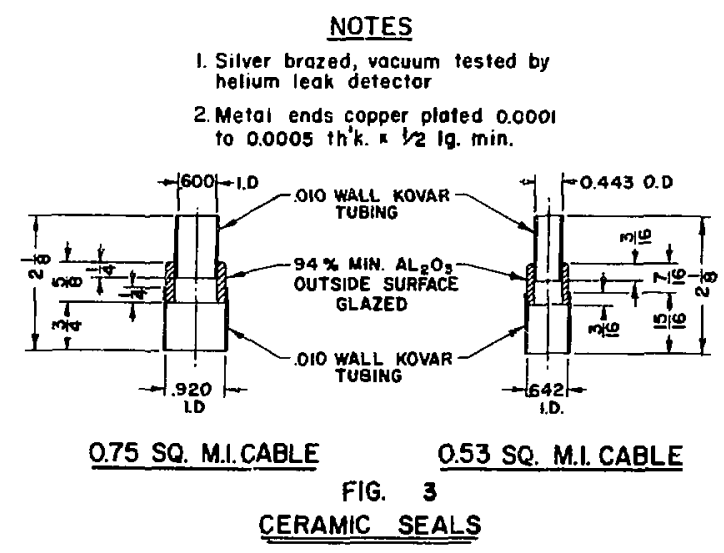

relatively easy; Kovar may be formed if pressure 1s applied to all four sides simultaneously. The conductor 18 machined to a more clrcular cross section (by a hollow mill in a hand drill) and the seal is soldered in place. Two soldering techniques are used, both intended to keep flux from reaching the Mgo insulation, which sertously and permanently degrades its insulation resistance. Note that the copper plating is essential for both methods.

\section{Soft-Soldering}

a) Tin the ends of the ceranlc-to-metal seal with 50-50 solder (f1ux permitted), wash in hot water and dry. Check Insulation resistance and leak tightness.

b) Cut back the cable sheath to the required distance, clean copper slivers and dust from the Mgo surfaces, and thoroughly clean the copper (wire brush).

c) Put a temporary epoxy seal in the end of the Mgo. We suggest Hysol 615 or Astrodyne Therwal-Bond 312."

d) Mill the conductor section exposed, and check that the seal fits.

e) Tin an inch or two of cable sheath and adjacent conductor w1th 50-50 solder (flux permitted), wash and dry.

\footnotetext{
"The Hysol epoxy is fast-getting (3-5 min) but will not tolerate a warm cable. If the cable has been warmed (to drive out molsture) the Astrodyne epoxy can be applled satisfactorily: 1ts drying time then $18 \frac{1}{4}-6$ hours depending on the temperature.
}

f) Remove temporary epoxy seal completely and check cable insulation resistance. Dry out if necessary.

8) Put seal in place and solder using no flux and $I$ reducing torch flame. Bulld up a substantial layer of solder at both joints.

h) Recheck cable insulation resistance and follow for a day or two for signs of molsture penerration.

2. Hard-Soldering

a) Cut back the cable sheath to the required distance, clean copper slivers and dust from the MgO surface, and thoroughly clean the copper (wire brush).

b) Fut a temporary epoxy seal in the end of the Mgo. We suggest Hysol 615 or Astrodyne Thermal-Bond 312.

c) Mill the conductor section exposed and check that the seal fits. Note that in this case the epoxy seal serves largely to avold losing MgO powiter from the annulus during this operation.

d) Remove the epoxy seal completely and check the cable insulation resistance. Dry out if necessary.

e) Put seal in place and braze ends to copper using AWS BCuP-5 (S11fos) using no flux.

f) Recheck cable insulation resistance and follow for a day or two for sigrıs of moi:-ture penetration.

Although the second technique has fewer steps, It regus res more skfll of the operator since the higher melting point of the solder Increases the rlsk of damsing the ceramic-to-metal seal. It is now the preferred method at this laboratory.

The seals used at LAMPF are of ofmple, inexpensive design. They are avallable from a number of ceramic-to-metal seal manufacturers. " If high conductor temperatures or rapid changes in current

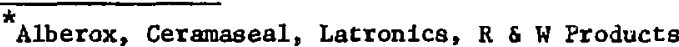


are enticlpated, which might cause relative movement between conductor and sheath, seals can be made with a flextble metal disc incorporated in the end, to minimize the strain on the ceramic.

There may also be situations where radiationhardening of the seal is not necessary. Then an epoxy seal (simllar to the pot seals provided by m.1. cable manufacturers for clrcular power cable) may be used. Removal of the $\mathrm{MgO}$ for $1 / 8^{\prime \prime}$ from the end, and filling this space with epoxy well bonded to the conduct or and sheath provides a seal of good strength. A plece of $1^{\prime \prime} 1$.d. copper tubing, an iach long, can be squared for $1 / 2^{\prime \prime}$ and used as a pot on the $0.751 \mathrm{n}$. sq cable.

All seals require that care be taken in subsequent handilng or manipulation of the cable end to avold mechanical damage. At LASL seal installation is an In-house operatior, and one of the last to be performed on the magnet.

Directly-Cooled Colls

Winding. Techniques for winding hollow m.1. cable are again quite conventional apart from $1 n-$ sulation application. It is desirable to keep the conductor bore sealed to prevent forelgn material entering the crolant passage, and, as with all operations on m.1. cable, the Mgo should be sealed.
Cooling Connections. Direct $1 y$-cooled conductors require Insulating connections to water beaders and to replace the rubber or synthetic hoses used in conventional magnets, we install ceramic water Insulators. Figure 4 shows two sizes. These are destgned to provide a long water path of mintmal cross section to keep the leakage current through the water low (a radiation environment will decrease the water resistivity even though $a \mathrm{high}$ initial value -- $1 \mathrm{M}$ - $\mathrm{cm}$ at LAMPF -- is maintained). There is reason to believe that deposition of contaminants inside the insulator (generally copper oxide) 1s more dependent on the total voltage across the insulator than on the voltage gradient, ${ }^{4}$ so the short lengths of these ceramic tubes compared to hoses may not be a great disadvantage. Maintaining a low oxygen content in the water also helps.

To evaluate the possible problems in a radiation environment an assembly of two of these insulators ( 3 " long $x 1 / 4 "$ 1.d. $\mathrm{Al}_{2} \mathrm{O}_{3}$ tube in $\mathrm{F} 1 \mathrm{~g}$. 4) was Irradiated In LASL's Omega West Reactor. Each Insulator was in a $300 \mathrm{pel}$ water clrcult with $100 \mathrm{~V} \mathrm{dc}$ across it. After a total radiation dose of $5 \times 10^{11} \mathrm{rad}$ the insulation resistance of these Insulators had dropped from $>5 \mathrm{~T} \Omega$ to 0.7 and $1.7 \mathrm{G} \Omega$ respectively. There was some internal deposit on
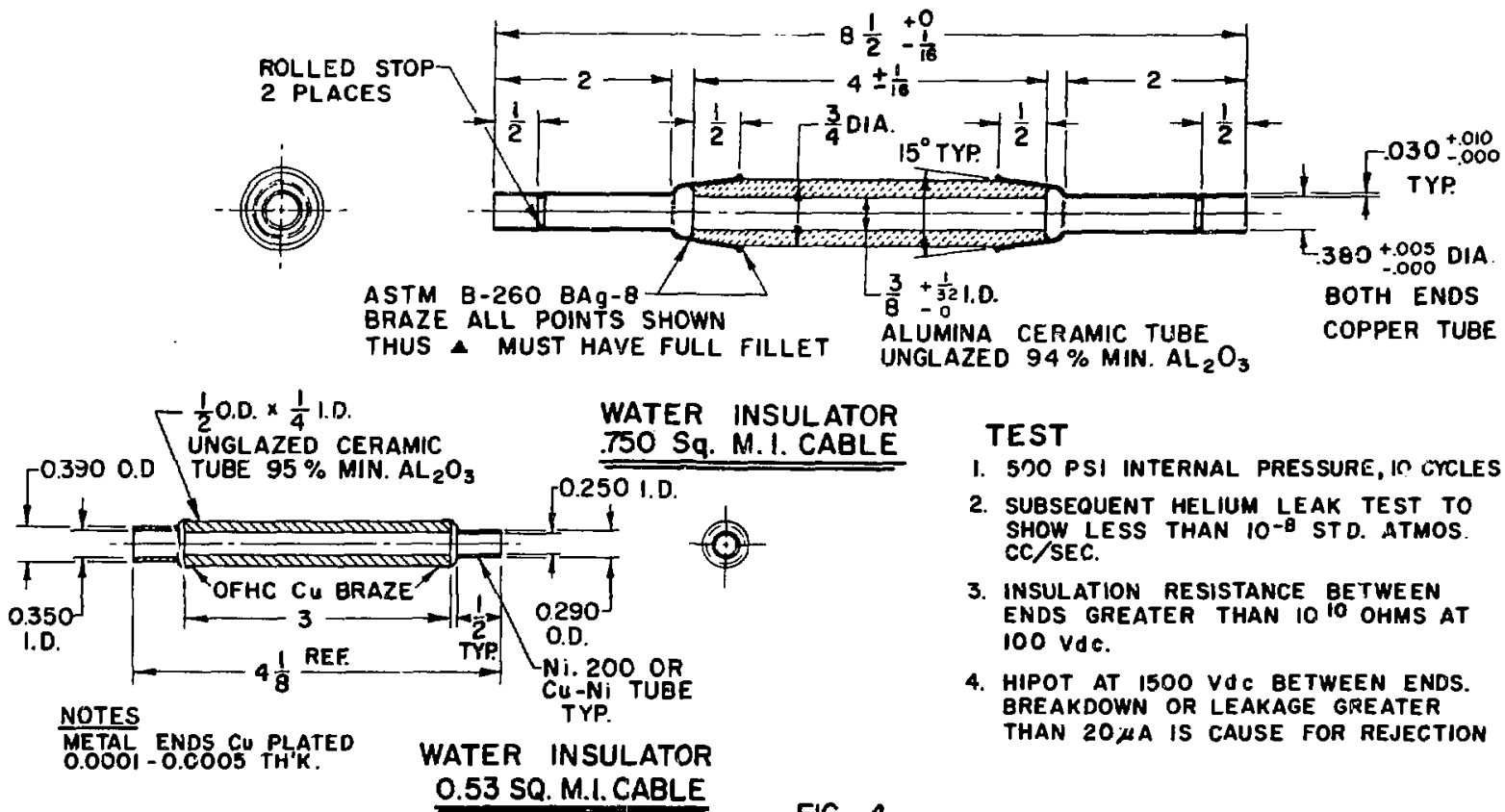

TEST

I. SDO PSI INTERNAL PRESSURE, IO CMLLES

2. SUBSEOUENT HELIUM LEAK TEST TO SHOW LESS THAN $10^{-\theta}$ STD. ATMOS CC/SEC.

3. INSULATION RESISTANCE BETWEEN ENDS GREATER THAN 1010 OHMS AT 100 Vde.

4. HIPOT AT 1500 VAC BETWEEN ENDS. BREAKDOWN OR LEAKAGE GREATER THAN $20 \mu$ A IS CAUSE FOR REJECTION

FIG. 4 
the ceramic tube, but obviously they were still adequate insulators.

The connections from conductor to insulator, and insulator to manifold, are made with annealed copper tubing. Two bends in orthogonal planes provide adequate strain relief for the ceramic tube, but we also put a tube fitting at each end of the insulator assembly to facilitate replacement.

Figure 5 is a photograph of an $8^{\prime \prime}$ quadrupole with these insulators installed.

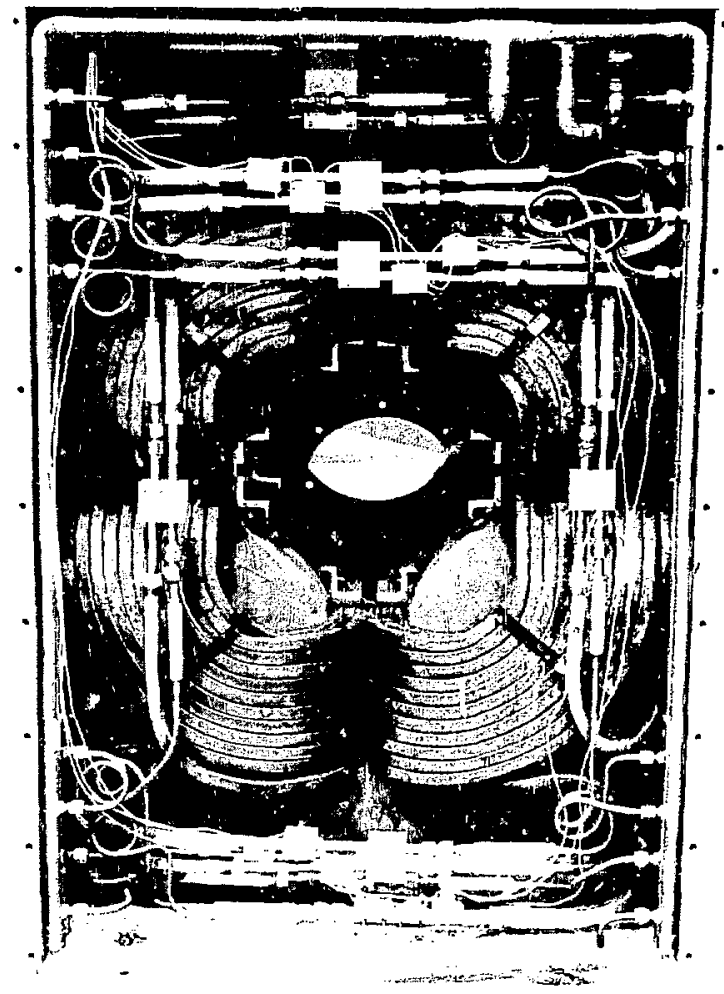

Fig. 5. 8" bore narrow quadrupole ( $8 Q \mathrm{QN} 16 \mathrm{M} / 7$ ) with ceramic seals, water insulators and temperature switch interlocks installed. Connections at top.

Joints in the water systems are made using 95Sn-5St solder, a higher-strength soft-solder because of the relatively high pressure (300 psi) cooling water.

Repairs

Since damage to coils in fabrication or assembly seems inevitable, it is worthwhile to say something of repair techniques. Any penetration of the outer copper sheath allows ingress of atmospherac molsture, and the insulation resistance of the cable drops. Note that the moisture penetration into the $M g O$ is slow, because of the tight packing, and is limited by the conversion of $\mathrm{MgO}$ to $\mathrm{Mg}(\mathrm{OH})_{2}$, with an increase in volume. This limits the moisture penetration from any exposed insulation to a foot or so. However, if the exposure to moisture has been long enough to form magnesium hydroxide, the cable has to be heated to $350^{\circ} \mathrm{C}$ minimum to drive off the water.

Diagnostics. A hole in the cable sheath can be found, if the cable insulation resistance is reasonably high, say over 10N4, by wetting the sheath locally. A wet cloth or spray bottle is convenient. A continuously-reading megohmmeter ${ }^{*}$ on the cable will show a marked decrease in L.R. when the water enters the hole -- and the effect is immediace.

However, probably a better test is to use a medium-sized oxy-acetylene torci flame, because this will provide an indication on the megohmmeter whatever the initial I.R. is (in fact, if it is below the megohm range, an ohmmeter may be used). The cable requires to be warmed only slightly, and an indication will be noted on the meter when the flame is directed at a moist patch in the cable.

Repair. Faced with a hole in the sheath, there are two possible courses of action. For a small hole less than $1 / 16^{\prime \prime}$ in any direction, it may be sealed using AWS BCuP-5 (Silfos) with no flux. This may be filed to give a flush surface. But larger holes require a patch of copper foil, again brazed on without flux. Trying to cover a large hole directly with Silfos generally results in the corch flame blowing MgO from the cable, so that the braze metal either contacts, or is very close to, the conductor, and no dielectric remains. In contrast, the space behind a patch may be packed with dry Mgo powder and the final cable properties are unaffected. The ourside dimensions, however, are increased.

Similar techniques are used to produce cable splices as illustrated in Ref. 2 . In every case the vital point is to avoid contaninating the MgO insulation.

\section{Specifications}

It has been LASL practice to specify the wound coill tests as follows:

* General Radio Type 1863, 1864 or 1644. 


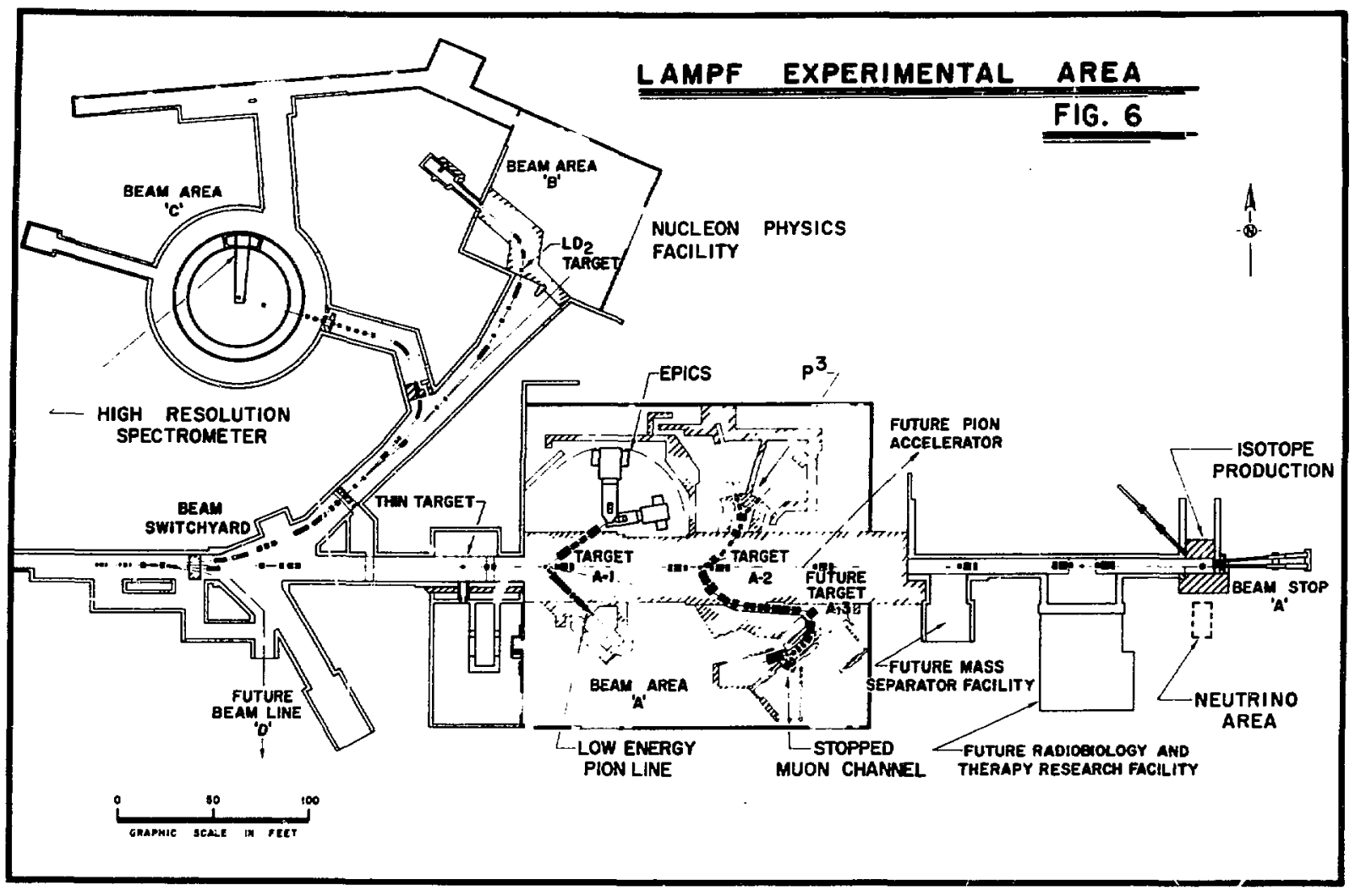

1. Insulation Resistance. A value $1 / 10$ of the cable "as supplied" resistance. For a typical

200 ft plece of cable, the cable manufacturer's specification calls for $250 \Omega$, so the coll winder is required $=\bar{v} z$ intain $2 \frac{1}{2} G \Omega$ in the finished section. Note that in a magnet with 16 coll sections, this w.11 give a completed magnet ground resistance of $156 \mathrm{M}$ minimum, which $1 \mathrm{~s}$ generally more than sufficlent for any loakage or regulation requirements. LASL expertence has been that much higher readings are obtaIned ( $i$ to $10 G \Omega$ ). If that level can be maintained for a week, this provides a good indication that all the seals are hermetic, and the Insulation resistance w111 then remain constant. Beware of lowered resistance readings caused by molsture or dirt on the outside of seals, or high-conductivity water Inside insulators.

2. H1pot Test. The coll high-potential test is spectfled as $1500 \mathrm{~V} \mathrm{dc}$, giving an applied voltage 0.7 times that used for the cable.
3. Water Flow. The same maximum pressure drop for the required water flow rate is specified for the coll as for the cable. Since the cables made so far are able to meet the pressure drop requirement comfortably, we have not encountered any problem in requiring the same flow admittance in the coll, despite some quite complex geometries (see next section).

\section{MAGNETS}

Figure 6 shows the general layout of the LAMPF switchyard and experimental areas.

\section{LAMPF Switchyard}

The magnets for the LAMPF switchyard have been briefly described. 5 These magnets have been in operation since June 1972, and FIg. 7 shows some of the switchyard.

LAYPF Experimental Area

Higher power magnets are required in the experimental area, although the medium-energy operation 


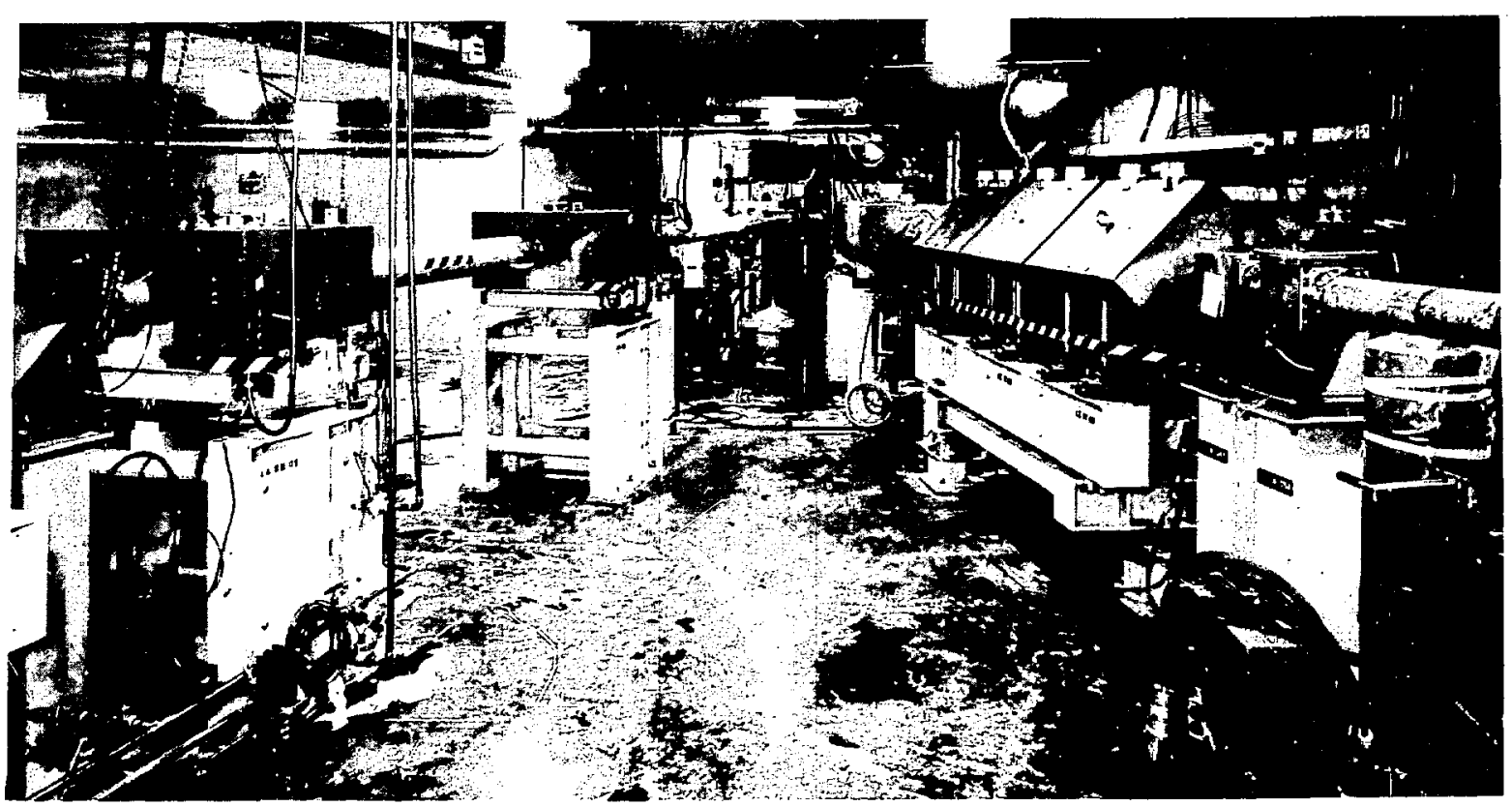

Fig. 7. LAMPF switchyard looking upstream. "Straight-through" beam line A on left; beam line $X$ (to areas $B$ and $C$ ) on right.

TABLE 9.

Magnet Designations Used at LAMPF

The following system is used to designate bending magnets and quadrupoles in this report. Inch units are used for dimensions:

Bending Magnets

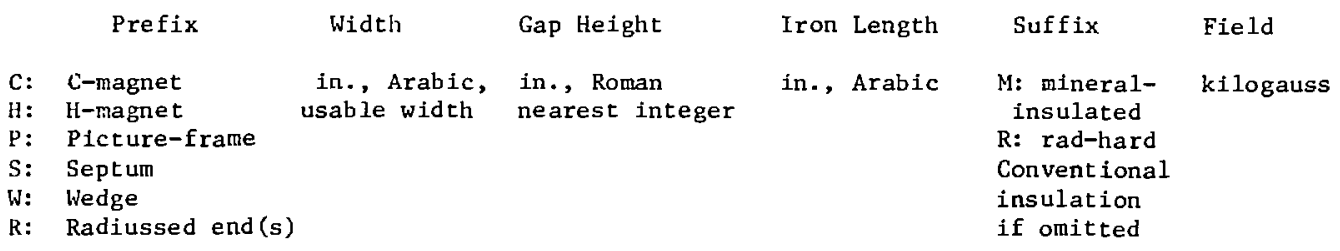

Example: HW20VI30R/15 is interpreted as a wedge H-magnet, 20" usable width, 6" gap, $30^{\prime \prime}$ iron length (on centerline), rad-hardened insulation, $15 \mathrm{kG}$ design flux density.

Quadrupoles

$\begin{array}{cllll}\text { Diameter } & Q & \text { Affix } & \text { Iron Length } & \text { Suffix } \\ \text { in., Arabic } & \text { E: elliptical } & \text { in., Arabic } & \text { M: mineral-insulated kilogauss at } \\ & \text { beam tube } & & & \text { R: rad-hard } \\ & \text { N: narrow } & & \text { Conventional } \\ \text { P: Panofsky } & & \text { insulation if } \\ \text { S: slim } & & \text { omitted }\end{array}$

Example: 8QN2OM/J is interpreted as an $8^{\prime \prime}$ bore narrow quadrupole, 20" iron length, with mineral-insulated coils, $5 \mathrm{~kg}$ at pole tip.

"Narrow" quadrupoles have overall width $=3 \times$ bore diameter.

"Slim" quadrupoles have overall width $=2 \mathrm{x}$ bore diameter. 
places the emphasis on field quality rather than high field strength. Bending magnets generally are 15-16 kG, and quadrupoles up to $9 \mathrm{kG}$ at the pole tip. The radiation environment for magnets in the target cells is estimated at $10^{11}-10^{12} \mathrm{rad} / \mathrm{yr}$.

Bending Magnets. Most experimental area bending magnets use $0.75^{\prime \prime} \mathrm{sq}$ hollow m. i. cable (Table 6) rated at $1800 \mathrm{~A}$ in lengths up to $220 \mathrm{ft}$, or at $2000 \mathrm{~A}$ in lengths up to $100 \mathrm{ft}$. The LANPF cooling water system is $300 \mathrm{psi}$, an important factor in allowing the use of long cable lengths.

These magnets vary in complexity: Fig. 8 shows a PR24YI37M/15* with adjustable shoes on the field clamp to trim the effective field boundary to the required radius. The saddle coils have one concave and one convex end, which require care in winding to avoid twisting the cable at the bends.

Pole shaping is used on the C7III32M $/ 16^{*}$ (Fig. 9) to improve field uniformity. See section v. The packing factor in these coils (defined as nominal copper cross-section divided by total coil space in the magnet) is $44 \%$-- the same as is achieved in cement-potted coils ${ }^{6}$ at LASL. From the limited ॠsee Table 9 . information available, ${ }^{7}$ i.t appears that other forms of cement potting could five packing factors of about $50 \%$.

Quadrupoles. Quadrupoles use the $0.53^{\circ} \mathrm{sq}$ hollow m.i. cable (Table 5). Their mechanical design depends heavily on the L.BL design of narrow quadrupoles. $^{8}$ Provided that the basic pole blocks for these magnets are made rectangular initially (Blanchard grinding is recommended) the magnet assembly requires little adjustment to produce symmetry and so a low sextupole component.

Po..e shaping for tinese quadrupoles was done at LASL (see Section $v$ ), and the pole-end chamfering to reduce duodecapole to an acceptable level was performed at LASL as described in Ref. 9. The measured values obtained for two sizes of quadrupoles are given in Table 10.

TABLE 10.

Pole Tip Integrated

Current Field Harmonics as $\%$ of $n=2$

\begin{tabular}{llllll} 
Mlagnet & $\mathrm{A}$ & $\mathrm{kG}$ & $\mathrm{n}=3$ & $\mathrm{n}=6$ & $\mathrm{n}=10$ \\
\hline 8QN16:1/7 & 750 & 6.7 & 0.033 & $<0.1$ & 0.026 \\
\hline $1 \mathrm{QQN}_{22 \mathrm{~N} / 9}$ & 750 & 9.1 & 0.022 & 0.07 & 0.01 \\
\hline
\end{tabular}

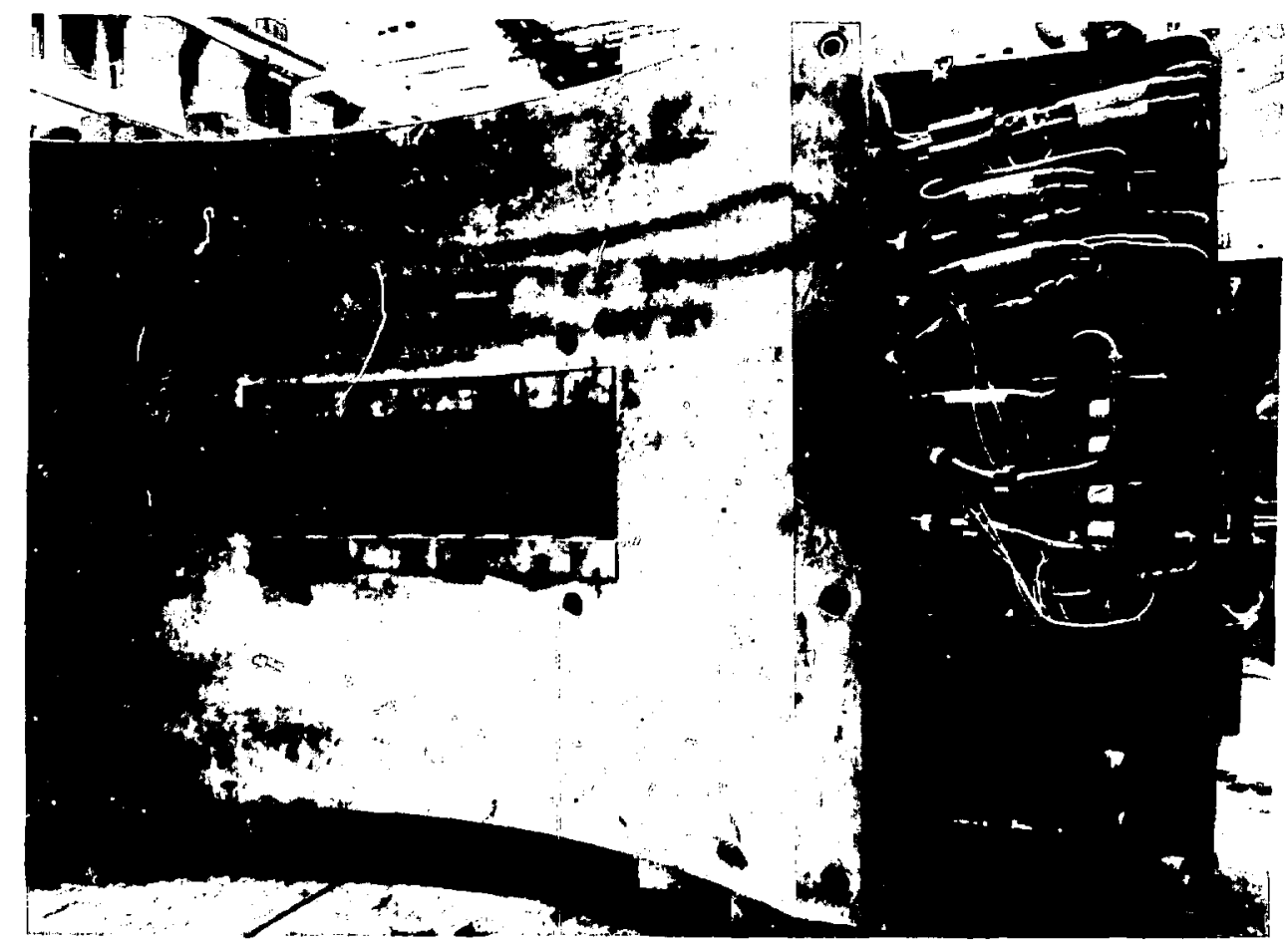

Fig. 8. PR24VI37M/15 bending magnet with radiussed ends and adjustable field clamp. Wound with 0.75 in. sq. m. i. cable. 


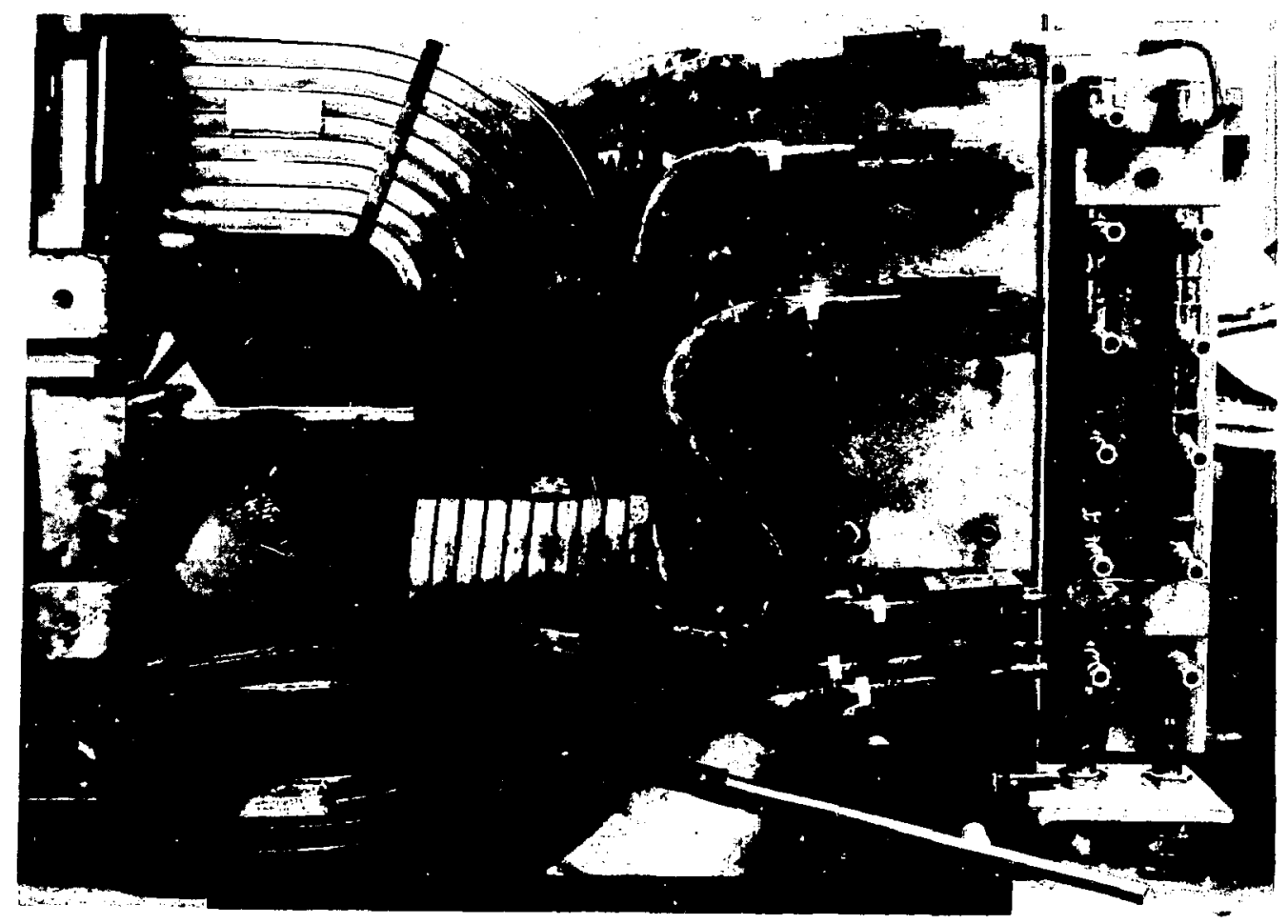

Fig. 9. C7III32M/16 bending magnet, partly completed. This photo shows clearly that a bend in the $0.75^{\prime \prime}$ sq. m.i. cable made on the coil form is smooth, but an unsupported bend of the same radius made in the leads produces wrinkles in the sheath.

Costs. To illustrate the contention that the overall cost of a mineral-insulated magnet is not very different from a conventional one, we list in Table 11 the costs of magnets procured for LAMPF. Magnets with an $M$ before the slash are mineralinsulated; those without generally have epoxyfiberglass insulated coils. Note, however, that the cost of applying seals and insulators to the mineral-insulated coils is not included in these costs. LASL experience to date indicates that an average of about a man-month of labor is required in addition to the hardware, making this operation cost about $\$ 2,000$ per magnet, for directly-cooled magnets. Magnets in the table are listed in order of increasing weight, but there is no indication of the quality of the magnetic field, an important factor.

Magnet Characteristics. Two features of m. 1 . cable wound magnets are worth mentioning. First, the sheath surrounding the conductor acts as a transformer secondary of low impedance, so that ripple voltage from a power supply will cause ripple current to flow in the coll to an extent not seen in conventional coils. The power supply designer has to be prepared for this low inductance. However, the balencing sheath current suppresses the ripple in the magnetic field to the same level as in a conventional magnet. See Ref. 10.

The sheath also serves as a shield for elictrical noise (if an SCR power supply is used, for instance). This can be a decided advantage if counting equipment is in the vicinity: obviously, the magnet leads have to be shielded as well, and at LAMPF many of these are also m.i. cable. This helps to maintain a low-noise environment for experimenters.

\section{v. POLE SHAPING}

\section{Genera1}

Two techniques have been used to determine pole shapes for the magnets described here. Shims for low-field bending magnets were derived by experiment, and the same shims were conformally transformed to produce poles for the 2 " quadrupoles.

Alternatively, the magnetostatic design program POISSON was used in an inversion program, MIRT, ${ }^{11}$ 


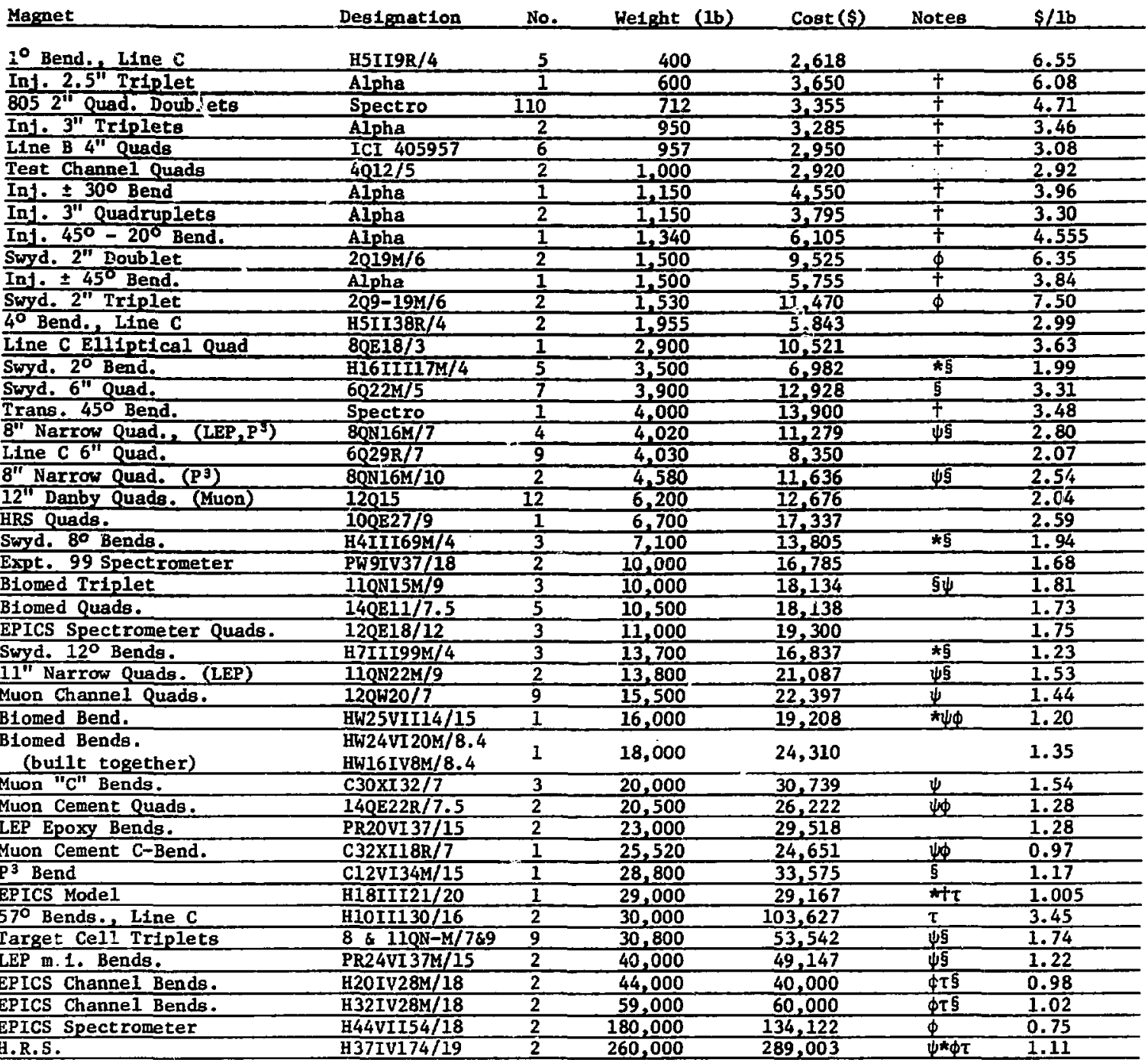

† Includes vendor design

* LASL supplied steel, Included in cost

$\psi$ LASL supplied conductor, Included in cost

$\S$ does not Include terminations and Interlocks, applied at LASL

$\phi$ assembly in-house at LASL

T has $\mathrm{H}_{\mathrm{T}}$ windings (Ref. 13) 
to optimize the pole profile in dipole geometry, and then to transform this optimized pole, if required, into quadrupole geometry. Thus, the two methods are basically similar, the first being empirtcal, while the second, sophisticated, method uses a CDC 6600 or 7600 computer. However, it may be noted in what follows that the first method was used primarily for the low-fleld switchyard magnets, while the latter was used for the higher-field expertmental area magnets. While meagurements on the switchyard magnets are now completed, those on the larger magnets are only now under way.

\section{Empiriral Approach}

Bending Magnets. Reference 5 gave one experimentally-derived shim-anti-shim combination, which was used on a LAMPF owltchyard bending magnet, the H10III69M/4. Figure 10 gives the measured field

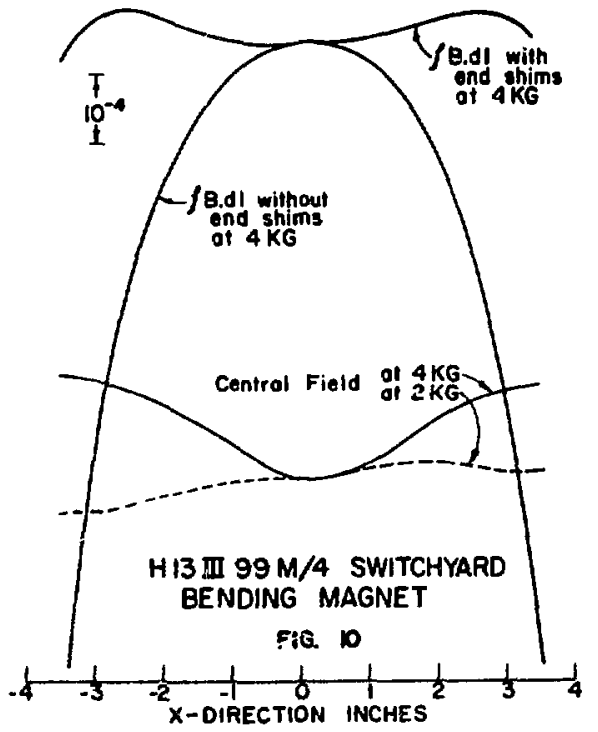

distributiou from another pole shape, at roughly $4 \mathrm{kG}$ and $2 \mathrm{kG}$. Also shown to the adjusted $f_{8} \cdot \mathrm{d} l$ scan across the magnet, showing the effect of the end shims used to correct for the fall-off at the corners. These end shims are pleces of low-carbon sheet steel emplrically chosen, and fastened to the pole ends. Their thickness varles from $0.028 \mathrm{In}$. to $0.104 \mathrm{in.,}$ and length (1.e., across the magnet width) from $1 \mathrm{ln}$. to $6 \mathrm{ln}$. Their outer sides are allgned with the pole edge, and the side nearest the gap tapers away from the pole face to give some

smoothing of the effect from stacked shims. Figure 11 shows a typical shim stack and the pole contoux. It

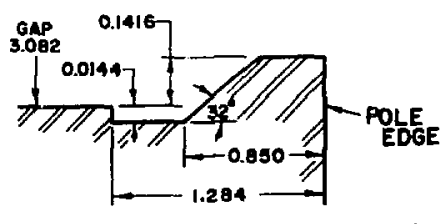

SHIM-ANTISHIM, HI3 II $99 \mathrm{M} / 4$

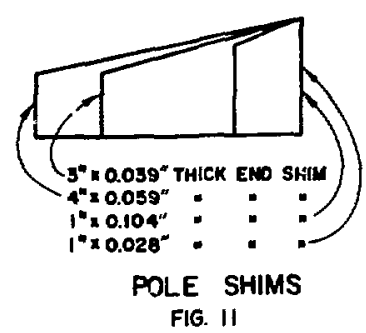

may be noted here that shimning as 1llustrated here, can only be done with low-fleld magnets. At higher fields the shim comers saturate, changing the fleld distribution. Even at low fields some change of effectiveness as a function of fleld strength can be observed.

Quadrupoles. Quadrupole poles may be derived from bending magnet poles by conformal transformatIon, and FIg. 12 shows a pole shape for a $2^{\prime \prime}$ bore quadrupole, 2Q19M/6 designed by the $x=x^{2}$ transformation from the H10III69M/4 bending magnet shim. 5

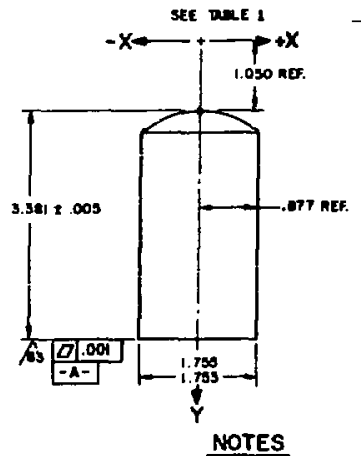

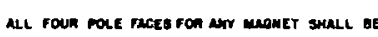

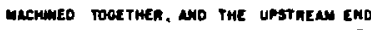

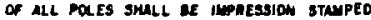
rOA IDEWTIFICASION

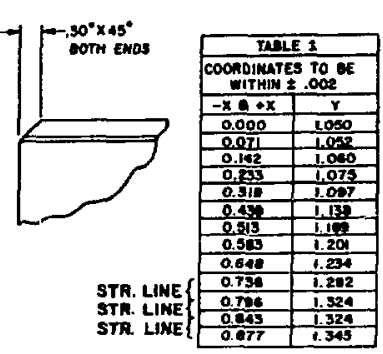

FIG. 12 $2019 \mathrm{M} / 6$ POLE 
Table 12 gives the measured harmonics for this quadrupole with a 0.3 In. $\times 45^{\circ}$ chamfer at the pole ends.

TABLE 12.

\begin{tabular}{|c|c|c|c|c|c|}
\hline \multirow[b]{2}{*}{ Magnet } & \multirow[b]{2}{*}{$\begin{array}{c}\text { Current } \\
\mathrm{A}\end{array}$} & \multirow{2}{*}{$\begin{array}{c}\text { Pole Tip } \\
\text { Fleld } \\
\text { kG }\end{array}$} & \multicolumn{3}{|c|}{ Integrated } \\
\hline & & & $\begin{array}{l}\text { Harmor } \\
\mathrm{n}=3\end{array}$ & $\begin{array}{c}1 \mathrm{cs} \text { as } \\
\mathrm{n}=6\end{array}$ & $\begin{array}{c}\% \text { of } n=2 \\
n=10\end{array}$ \\
\hline \multirow[t]{2}{*}{$2 Q 19 M / 6$} & 100 & 5.2 & 0.025 & 0.019 & 0.242 \\
\hline & 50 & 2.7 & 0.01 & 0.03 & 0.239 \\
\hline
\end{tabular}

Figure 13 shows the "adjustable box" construction used In the switchyard quadrupoles to achleve close symmetry tolerances: $0.004 \mathrm{in}$. on bore $\mathrm{d} 1-$ ameters and $0.002 \mathrm{in}$. between adjacent poles in the

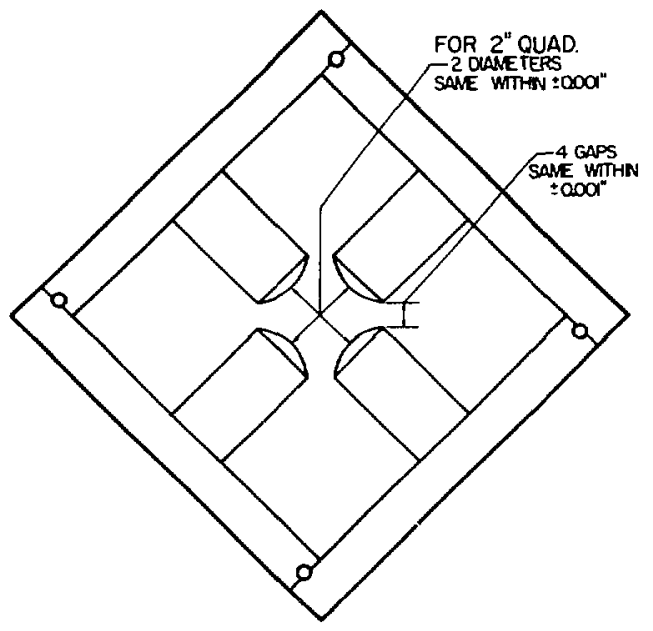

QUADRUPOLE SECTION

FIG. 13

6" bore quadrupole, and $0.001 \mathrm{in}$. (as shown $\mathrm{in}$ Fig. 13) for both measures in the 2 " bore quadrupoles.

A number of methods have been used to produce the shaped poles required: template-following planing, shaped milling cutcers and planing with a varlety of shaped tools to match a template. All seem to be satisfactory for the spectfled $\pm 0.002 \mathrm{in}$. tolerance on the pole tip contour.

Beam Tuteg. All beam tubes in the LAMPF switchyard quadrupole magnets are seamless austen1tic stainless steel; in the bending magnets, the rectangular beam tubes have the welds well away from the "good fleld" reglon. We have measured field perturbations of over 2 in $10^{4}$ due to welds in 304 stalnless steel made with no filler. If a filler rod is used, the perturbaton is larger. MIRT

More sophlsticated pole shaplng may be done with the help of computer-based megnetostatic programs. TRIM ${ }^{12}$ and POISSON solve the 2-dimensional field equations for arbitrarily-shaped 1ron boundarles, and can accomodate not only the conductora, but also differing permeabilities in sections of the magnet. These programs have the stvantage over the techniques in the previous section that smooth-contour shims can be incorporated, making saturation less of a problem. The inversion program $^{11}$ incorporated in MIRT is set up to allow the designer to vary the pole contour in designated areas to achleve the fleld uniformity required. The 3" gap, $16 \mathrm{kG}, \mathrm{C}$-magnet (C7III32M/16) has a calculated field unfformity of $0.5 \mathrm{G}$ over the $2 \mathrm{in}$. beam trajectory; the measured unfformity is $29 \mathrm{G}$ over 2" width, at $16 \mathrm{kG}$, but the discrepancy between calculation and measurement $1 \mathrm{~s}$ less at lower flelds, suggesting that saturation is not properly modeled in the computer program. Figure 9 is a photograph of this magnet nearing completion. Tab? - 13 is the coordinate table for an $11 \mathrm{in}$. bore quadrupole, $11 \mathrm{QN} 22 \mathrm{M} / 9$, with neglig1ble $\mathrm{n}=6$ (duodecapole).

TABLE 13.

Coordinate Table, 11QN22M/9

(Tolerance $= \pm 0.002$ ).

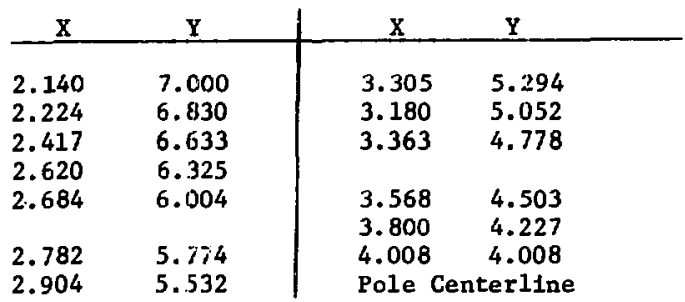

vi. ACKNOWLEDGMENTS

Many of the handling and terminating techniques for m.1. cables described here are the result of folnt efforts and discussions at Pyrotenax of Canada Ltd., and at LASL. The development works 
on producing hollow m.i. cable owes a great deal to the efforts of Mr. Sid Walker, plant manager of Pyrotenax. Group CAB-6 at LASL also helped in the early development work, and recently solder-cast some indirectly-cooled coils. The seal application has been developed and implemented by LASL technicians under the capable direction of Ted Montoya.

The MIRT computations were made by Ron Ycurd, now of LBL, while at LASL. Finally, the measurements reported here were taken by the LAMPF section formerly directed by him. Hassenzahl.

Magnets made using these techniques have been fabricated by a number of vendors in American industry: their skill has contributed to the success of this program.

I am also indebted to my colleagues at LAlPF who have provided cost data on the magnets for which they were responsible.

\section{References}

1. L. R. Glasgow and R. J. Burleigh, Nuc. Inst. \& Methods, 18, 19, 576-581, 1962.

2. A. Harvey and S. A. Walker, IEEE Trans. Nuc. Sci., NS-16, \#3, p. 611, June 1969.

3. A. Harvey, Proc. of 1970 Linac Conf., National Accelerator Laboratory, Batavia, IL, p. 709
4. W. O. Brunk, C. 4. Harris, D. B. lobhirs, IEET

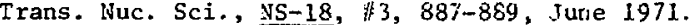

5. A. Harvey, R. D. Tumer, IEEE Trans. Nuc. Sri., NS-18, $\# 3,892-3$, June 1971.

6. A. F. Vogel and J. j. Rosenthal, "Cement-Potted liofls for Muon Channel Hagnets," LA-5115, P. 430 , 1972 .

7. A. J. Gresham, R. SineLion and G. B. Stapletor, "Mlagnets for Radiation-Resistant Accelerators," Particle Accelerators 4, p. 43, 1972.

8. K. 9. Lou, J. M. Hauptman, J. E. Walter, "HighQuality Narrow Quadrupole Magnets," I awrence Berkeley Laboratory Report, UCRL-18558, 1967.

9. W. V. Hassenzahl, "An Algorithm for Eliminating the Duodecapols Component in Quadrupole Magnets," ith Int. Conf. on Magnet Technology, 1972 , CONF. 720908

10. E. Schneider, "Ripple current and Flux in Mineral-Insulated Magnets," LA-5115, p. 403,1972.

1.1. K. Halbach, Proc. 2nd Int. Conf. on Magnet Technolog:, (Oxford, 1967) pp 47-59.

12. J. S. Colonias, J. H. Dorst, 1st Int. Symp. on Magnet Technology, SLAC, CONF-650922, pp 188$195,1965$.

13. K. Halback, "Field Correction Windings for Iron Nagnets," UCKL-18969, Nov. 1970.

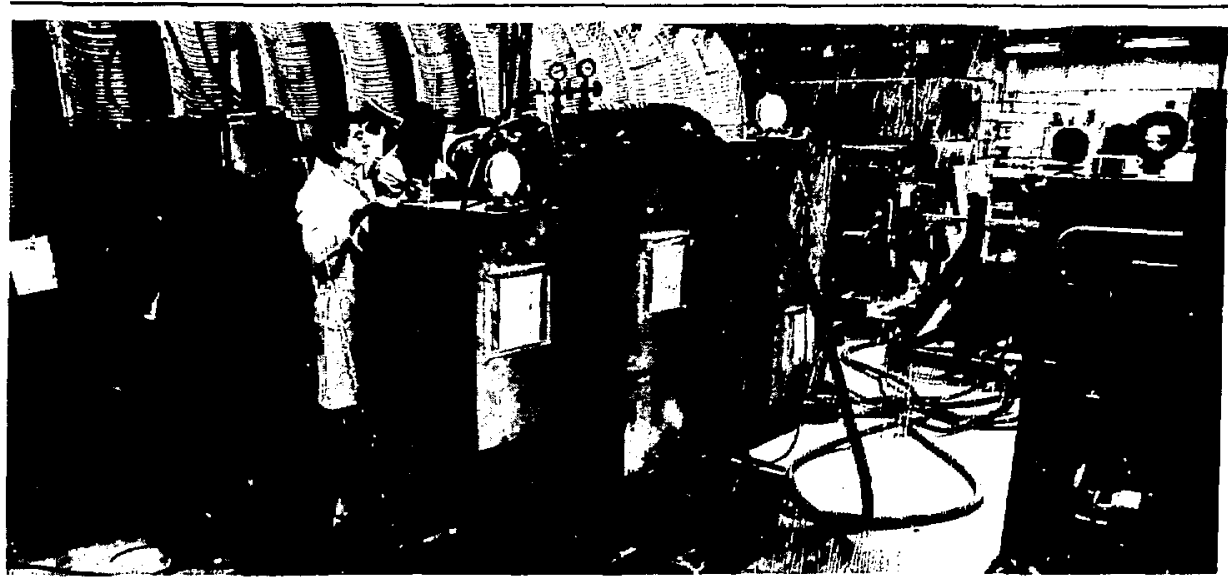

A target cell triplet quadrupole being set up for test in the experimental area at LAMPF by Lon Martinez and Ted Montoya. This entirely inotganic magnet ( $8 \mathrm{QN16M} / 7$ - 11QN32M/9 - 11QN15M/9) is arranged for remote handling -note the electrical and water connections on top, and the locating pins on the base. 